\title{
Pricking in the African Diaspora: Current Evidence and Recurrent Debates
}

\author{
Anna Wahlberg ${ }^{1} \cdot$ Jessica Påfs $^{2} \cdot$ Malin Jordal $^{3}$
}

Published online: 2 May 2019

(C) The Author(s) 2019

\begin{abstract}
Purpose of Review The purpose of this review is to assess current evidence and summarise key debates on pricking within the African diaspora.

Recent Findings Current evidence reveals divergent views regarding pricking. (Inter)national legislation is unspecific regarding the illegality of pricking, further complicated by the difficulty of detecting pricking due to a lack of visible change in the genitalia. Debates are polarised and pricking is commonly viewed from a 'harm reduction' or 'zero tolerance' approach. This means that pricking can be approved of as a strategy for minimising health risks of female genital cutting (FGC) while still allowing for cultural diversity, or rejected as a violation of girl's human rights and bodily integrity.

Summary Pricking is receiving increased attention, yet evidence from a migration context is still scarce. More research regarding the underlying reasons for supporting pricking, its potential harm, and whether it has a role in the eradication process of FGC is needed.
\end{abstract}

Keywords Female genital cutting $\cdot$ Female genital mutilation $\cdot$ Pricking $\cdot$ Symbolic circumcision $\cdot$ Migration

\section{Introduction}

With globalisation, discussions on the impact of migration on cultural change regarding female genital cutting (FGC) and of the possibility of alternative genital cutting rituals such as pricking (FGC type IV) are being held on national and international levels. The purpose of this review article is to assess current evidence and summarise key debates on pricking within the African diaspora.

This article is part of the Topical Collection on Sociocultural Issues and Epidemiology

Anna Wahlberg

anna.wahlberg@ki.se

1 Department of Women's and Children's Health, Division of Reproductive Health, Karolinska Institutet, Widerströmska Huset, Tomtebodavägen 18a, 17177 Stockholm, Sweden

2 Department of Neurobiology, Care Sciences and Society, Division of Social work, Karolinska Institutet, Stockholm, Sweden

3 Center for Gender Research, Uppsala University, Uppsala, Sweden
Pricking is here defined as a practice where the clitoris or the surrounding tissue is pricked with a sharp object, but where no tissue is removed. The World Health Organization (WHO) classifies pricking - along with other practices - as female genital cutting (FGC) type IV [1]. The practice of pricking is also referred to as 'symbolic circumcision', 'nicking', 'incision', 'FGC type IV', or 'sunna circumcision'. However, sometimes, these terminologies include practices where tissue is removed. For example, removal of tissue the 'size of a rice grain' has been labelled pricking [2]. Also the term 'sunna circumcision' can, at least in practice, involve a wide range of practices in addition to pricking, such as clitoridectomy, cutting, and scarification [3].

The phenomenon of pricking is largely understudied. The few existing studies are often prevalence studies with little explanation of the underlying reasons for doing it or of the consequences of pricking [4]. Such prevalence studies conducted in Africa reveals that the highest prevalence of pricking is found in Eritrea (46\%) and the Central African Republic (20\%) [5]. In some countries, such as Burkina Faso, Chad, Guinea, and Mali, more extensive types of FGC appear to be replaced with less extensive types. In these countries, pricking seems to have increased even if still relatively rare 
[6]. Similarly, in Kenya, pricking has been brought forward as an alternative to the traditional excision of the clitoris and/or labia, and described as important as it signified a 'psychological cut' marking the girl as a woman [7-9]. However, there is a concern that what is described as a 'prick' may indeed be a more severe form of FGC $[10,11]$. Thus, the role of pricking in the abandonment process remains largely unknown. In addition to pricking in African countries, where it is often described as part of a change to less extensive forms of FGC, pricking has been documented as a traditional practice in some Asian countries, including Indonesia, Malaysia, Thailand, and India. Here, it has been described as an important social tradition with religious importance [2, 12-17].

Due to migration from FGC-practicing countries, an estimated half a million women and girls with FGC live in Europe [18]. It has been suggested that migrants from countries practicing more extensive forms of FGC, such as infibulation, are likely to abandon FGC entirely or opt for pricking in the new context $[19,20 \bullet \bullet$. This is possibly a result of different factors such as inclusion in new social networks where FGC is not the norm, legislation against FGC, increased exposure to education, and discourses emphasising the harm involved in more extensive forms of FGC $[21,22]$. In a recent thesis from Sweden by the first author of this review, it was revealed that a majority of the Swedish Somalis opposed all forms of FGC, while about one fifth expressed a support for the continuation of pricking - suggesting a trend towards support of less extensive forms of $\mathrm{FGC} \mathrm{[23 \bullet ].}$

\section{Ongoing and Recurrent Controversies Surrounding Pricking}

During the last decades, there have been recurrent discussions and suggestions concerning how to view and legislate around pricking. In 1992, the Ministry of Welfare, Health and Culture in the Netherlands proposed that doctors should be allowed to perform an anaesthetised prick of the clitoral covering [24]. Similar suggestions were made in 1996 by the Harborview Medical Center in the USA [25], and in 2003 by the Department of Gynaecology, Perinatology and Reproduction Physiology of Florence in Italy [24]. In 2010, the American Academy of Pediatrics made a statement that a ritual nick is not physically harmful, less extensive than newborn male circumcision, and could be offered as a compromise solution to build trust between hospitals and immigrant communities [26]. Again in 2016, two medical doctors in the USA suggested that minor forms of FGC - such as pricking - should be accepted as a 'compromise that respects culture and religion but provides the necessary protections against child abuse' [27••]. In all these proposals, a medicalised pricking is understood as involving no or minimal risks and can as such be used as a harm reduction strategy to protect girls from undergoing more extensive forms of FGC. Implicit or explicit in these proposals is a view of pricking as 'harmless' and thus not 'child abuse'. However, all these suggestions have been met with strong opposition by advocates of a zero tolerance of any form of FGC, who precisely oppositely proclaim that also pricking is 'child abuse', represents gender discrimination, and is a violation of children's rights and bodily integrity [1, 28, 29••, 30]. Currently, no changes to allow pricking have been made in Europe or other western contexts.

\section{Attitudes and Practices}

While there are different perspectives of FGC within migrant communities, several studies report a high opposition towards all forms of FGC or a support of pricking (or 'sunna circumcision') [3, 19, 20••, 22, 31-38]. For example, a Dutch qualitative study with men and women from Somalia, Eritrea, Sierra Leone, and Egypt found that many discouraged infibulation, but supported pricking as this was seen as a lighter form of FGC while still sufficient 'to remain faithful to one's own culture' [39]. Yet, despite a proclaimed support of pricking, these participants expressed that they did not perform any kind of FGC on their daughters due to the perception that also pricking was strictly prohibited and thus feared losing custody of their children [39].

Yet, while attitudes and behaviour are related, individuals' attitudes are not always reflected in their behaviour [40]. Prevalence estimates are therefore of value. However, there are several challenges in estimating the prevalence of pricking in diaspora. Some relate to the current FGC legislations in place, but also to that pricking may not cause visible changes. Yet, there are some cases of reported pricking in the diaspora, most performed before migration. In a study at a UK safeguarding clinic, 27 girls (all but one originating from an African country) were confirmed to have undergone FGC. Among those, a majority-11 girls (41\%)—were diagnosed with FGC type IV. Six of these had evidence of a small genital scar, and five had normal genital appearance (pricking or nicking confirmed based on testimony) [41 •]. Similar findings were reported from a study at a paediatric FGC clinic in the UK, in which 11 out of 18 girls $(61 \%)$, the majority from Somalia, were diagnosed with FGC type IV. Ten had evidence of a small genital scar, while one had a normal genital examination but where the family confirmed that the girl had been cut [42]. Cases of type IV cutting, which may involve pricking, were also reported in a cross-sectional study among paediatricians/child health specialists in Australia where 6 out of 23 girls (23\%) were classified as having FGC type IV [43]. The majority of identified cases of pricking (or FGC type IV) in these studies were performed before migration from a country where FGC type I-III are most prevalent [41•, 42, 43]. This could indicate a possible shift from FGC type I-III towards FGC type IV/pricking already in the country of origin. Yet, 
based on these few hospital-based studies, it cannot be concluded whether such a shift is actually taking place.

\section{Ambiguities in Legislation}

While FGC is legislated against in all EU member states [44], the wording in national and international legislation against FGC usually mentions practices that 'mutilate' the female genitals or involve the removal of genital tissue. For example, in the Swedish Act prohibiting FGC, it is stated that (translated from Swedish, emphasis not original): 'Operations on the external female genitals with the aim to mutilate them or produce other permanent changes in them (genital mutilation) must not take place' [45]. Yet, in the Swedish context, pricking was mentioned in the preparatory work of the Act on FGC, thus the practice is interpreted as illegal, which may also be the case in other countries. The Council of Europe Convention on Preventing and Combating Violence against Women and Domestic Violence (the Istanbul Convention) states that the following practices should be criminalised: 'excising, infibulating or performing any other mutilation to the whole or any part of a woman's labia majora, labia minora or clitoris' [46]. As pricking does not include any removal of tissue and does not signify 'mutilation', it may be difficult to interpret the (il)legality of pricking. This has been demonstrated in two court cases concerning pricking (or 'khatna') among the Dawoodi Bohra community in Australia and the USA. In Australia, the three individuals who were convicted for being involved in arranging pricking on two girls were later acquitted on all grounds as no physical alteration of the genitals could be seen [47, 48]. And in another case in the USA, charges against several individuals for being involved in performing what appears to be some form of pricking were dismissed as the law was ruled to be unconstitutional $[49,50]$. Also, to determine whether a practice that may not leave any visible trace has taken place will in most cases require that the girl was old enough to remember it, or that her caregivers admit she has been subjected to pricking. In contexts where pricking is illegal, obtaining such statements from the caregivers is unlikely as they would risk being convicted for a crime. Altogether, these factors complicate legal processes against pricking.

Further, differing laws on male circumcision versus FGC, in which girls are legally protected from all forms of nontherapeutic genital cutting while boys are not, is argued by Darby to represent a gender bias where girls are favoured over boys [51]. It has therefore been argued that circumcision of boys, just like all forms of FGC, should be prohibited [29••]. On the contrary, this 'gender bias' has also been used as an argument that some forms of FGC must be tolerated when circumcision of boys is [27••]. This has also been recognised by migrants in the African diaspora. For example, Hernlund writes, reflecting on a conversation with two Somali women following a Seattle seminar for health care providers and refugee women: 'It had not occurred to these extremely bright, articulate, and politically astute women professionals that a simple pinprick of the clitoris could be illegal under U.S. law, while their own sons legally underwent much more invasive procedures.' [52]. This 'gender bias' has been used by defence attorneys in legal cases arguing that pricking of girls' genitals ought to be legal as long as removal of genital tissue from boys is [53]. As these controversies illustrate, the question of legalising pricking or not rests in different perspectives and cannot be resolved easily.

\section{The Question of 'Harm'}

Less extensive forms of FGC, such as pricking, have been suggested as a strategy to minimise harm $[27 \bullet \bullet, 54,55]$. One important aspect in the so-called harm reduction approach is to accept a milder form of FGC as a first step towards complete abolishment of the practice. Another is to allow for diverse religious and traditional practices important for minority populations living in a country where FGC is not traditionally practiced and/or outlawed [14, 27••, 56]. However, this approach has been contested by those supporting a zero tolerance approach towards FGC. They argue that making a distinction between 'high risk' and 'low risk' forms of FGC in regard to health complications might be interpreted as condoning the 'low risk' form(s) and thereby undermining efforts to end FGC completely $[57,58]$. There is also a fear that girls who have been pricked will have to go through a second, more extensive, cutting in the future [59]. Further, there seems to be disagreement, largely based on lack of empirical studies, regarding the possibility of negative psychological, physical, and sexual consequences of pricking. In a review of immediate health consequences of FGC, the authors found that also 'nicking' presented a risk of such complications [60]. However, they pointed out uncertainties of the validity of the findings, mainly due to challenges in determining the extent of tissue removed or altered. As pricking involves no removal of tissue, some argue that a medically safe pricking would have limited or no impact on health and sexual function [27••, 48, $61,62]$. Yet, even though pricking involves no removal of tissue, one cannot exclude the possibility that pricking procedures may cause psychological consequences and have a negative impact on sexuality when performed on girls who are too young to consent or make informed choices. Studies are therefore needed to elucidate possible effects of pricking on women's psychological well-being and sexuality. Also within the Somali diaspora in Sweden, there were divergent views of the possible negative health effects of pricking; some made the conclusion that it cannot completely be ruled out that pricking causes no harm, while others were of the opinion that a practice resulting in no visible change cannot cause any harm $[63 \bullet \bullet$. 
The previously mentioned suggestions from the Netherlands, USA, and Italy [24] entail that pricking should be performed in a medical setting with sterile equipment and anaesthesia. This argument has also been made by Swedish Somalis [63・*. Opponents of such medicalisation of pricking argue that allowing pricking to be performed in a medical setting is a violation of health care ethics as there are no clinical reasons for having it performed. Furthermore, it is said that the risk of health complications such as infections and bleeding can never be completely avoided, even if performed in a medical setting [64-66]. It is also argued that whether pricking is harmful cannot be used as grounds for determining if it should be allowed. Rather, pricking performed on girls who are too young to consent or make informed choices is viewed as a violation of girls' human rights and bodily integrity $[10,29 \bullet \cdot]$. Another argument is that allowing pricking to be practised in a medical setting poses a risk that other practices of FGC will become normalised and legitimised, thereby impeding the work to abolish all forms of FGC $[10,65]$. However, evidence regarding the effect of medicalisation on the prevalence of FGC in general is conflicting [67]. For example, a study based on data from 25 countries in African and the Middle East could not demonstrate an association between medicalisation and rates of decline, or increase, in the prevalence of FGC [68]. It remains a question to whether similar findings would occur if considering only pricking.

Medical practitioners' views on pricking are diverse. In a survey among gynaecologists in Belgium, 51\% (155/306) rejected a symbolic incision/pricking as an alternative to FGC, while $47 \%$ expressed a support for such a strategy. Further, 77\% (243/317) did not support medicalisation of FGC as a harm reduction strategy, while $21 \%$ were positive towards such a strategy. Many expressed that they wanted more clarity in the ethical-legal issues of practices such as symbolic incisions [69], something which has also been reported among midwives in Belgium [70].

\section{Cultural and Religious Perspectives}

The perception that FGC is related to religion is particularly the case for practices termed 'sunna circumcision', in which pricking usually is included. In Islam, the term 'sunna' means 'the tradition of the Prophet Mohammed' [71]. The SomaliNorwegian researcher Gele has expressed a concern that, although pricking seems to commonly be viewed as 'sunna circumcision' and accepted by religion, individuals arguing to support pricking or 'sunna' may in actuality practice a more extensive form of FGC [72], a concern also echoed by the WHO [1]. Similarly, Hernlund observes that 'sunna circumcision' for some Somali women entails a nicking, while for others, it entails a pinch of the clitoral prepuce with a verbal declaration of altered status [52]. While these authors refer to 'sunna' more than pricking, it is interesting to consider that terminologies used to describe different genital cutting practices sometimes are mixed together and may mean different things to different people. Similarly, among Swedish Somalis, $32 \%(198 / 612)$ did not define pricking as a form of FGC $[20 \bullet 0$. Thus, there is a risk of a 'mismatch' between individuals' and (inter)national organisations and governments' views of what practices are defined as FGC. This emphasises the need to be specific to what practices one is referring to, both in research and anti-FGC campaigns. However, the majority $91 \%(560 / 616)$ of Swedish Somalis in the above-mentioned study knew that also pricking is illegal in Sweden [20••], indicating an awareness of the dominant definition of FGC.

The religious imperative in the continuation or abandonment of FGC is worth considering. Encounters with other Muslims in diaspora are suggested to lead to a 'redefinition' of what characterises a good Muslim, where prior FGCsupporters start to question the religious imperative of FGC. As a result, while infibulation is increasingly viewed as unIslamic, some may still support 'sunna circumcision', which is often synonymised with pricking, based on a religious rationale $[3,19,63 \bullet \bullet, 73]$. Qualitative studies from the Somali diaspora in Sweden show that some perceive pricking as an acceptable or even beneficial religious practice [63••]. It is yet largely underexplored whether pricking could be replaced with other completely non-invasive, symbolically, practices while still keeping its perceived religious value.

After migration, pricking has been described as a way to balance between the 'old' and 'new' culture in that one replaces the traditional form of FGC with a less extensive form [63・•]. This could be seen as a willingness for FGC-practicing migrants to adapt to their new social context/society, without totally giving up their cultural practices. In a study with Swedish Somalis, pricking was perceived by 10\% (64/611) as a way to ensure respectability [20••], yet little is known about how this connection was made. Further, some supported pricking on the basis that it was perceived not to have a negative impact on health or sexuality [63••]. This is interesting since a commonly mentioned motive of FGC is to ensure chastity or limiting excessive female sexuality. For example, infibulation has been described as a way to create a culturally constructed virginity in Somali populations [74]. How infibulation can be replaced with pricking and still imply meaning for those practicing it, needs to be further explored.

\section{Conclusion}

The issue of pricking is a moot point, stirring strong emotions, controversy, and recurrent debates. It is not only a question of whether or not pricking is harmful, but debates on pricking 
also revolve around issues of bodily integrity, consent, gender, autonomy, and cultural diversity.

To summarise some of the key debates in this review, arguments for a harm reduction approach in which medicalised pricking would be allowed include that it would involve no or minimal risks, and could protect girls from undergoing more extensive forms of FGC. This view is also used as an argument for tolerance and cultural diversity as, for some, pricking is important for cultural and/or religious identity. Further, this approach is argued to be more effective in achieving change than condemnation. On the other hand, proponents of the zero tolerance stand argue that such a liberation of FGC could signal approval of non-consented harmful practices towards children, patriarchal oppression, and violation of bodily integrity.

The conclusion of this review is that while there is an increasing attention around the phenomenon of pricking, empirical research — especially within a migration context—is still scarce. More research is needed, particularly regarding the underlying reasons for supporting pricking, its potential harm, and whether it has a role in the eradication process of FGC.

\section{Compliance with Ethical Standards}

Conflict of Interest The authors declare that they have no conflict of interest.

Human and Animal Rights and Informed Consent This article does not contain any studies with human or animal subjects performed by any of the authors.

Open Access This article is distributed under the terms of the Creative Commons Attribution 4.0 International License (http:// creativecommons.org/licenses/by/4.0/), which permits unrestricted use, distribution, and reproduction in any medium, provided you give appropriate credit to the original author(s) and the source, provide a link to the Creative Commons license, and indicate if changes were made.

\section{References}

Papers of particular interest, published recently, have been highlighted as:

- Of importance

•- Of major importance

1. World Health Organization. Eliminating female genital mutilation: an interagency statement UNAIDS, UNPD, UNECA, UNESCO, UNFPA, UNHCHR, UNHCR, UNICEF, UNIFEM, WHO. Geneva; 2008.

2. Clarence-Smith WG. Islam and female genital cutting in southeast Asia: the weight of the past. Finish Journal of Ethnicity and Migration. 2008;3(2).

3. Catania L, Mastrullo R, Caselli A, Cecere R, Abdulcadir O, Abdulcadir J. Female genital mutilation/cutting: perspectives of men from Benin, Eritrea, Egypt, Ethiopia, Nigeria and Somalia after migration to Italy. International Journal of Human Rights in Healthcare. 2016;9(1).

4. United Nations Children's Fund. Female genital mutilation/cutting. A statistical overview and exploration of the dynamics of change. New York; 2013.

5. Shell-Duncan B, Naik R, Feldman-Jacobs C. A state-of-the-art synthesis on female genital mutilation/cutting: what do we know? New York; 2016. http://www.popcouncil.org/ EvidencetoEndFGM-C.

6. Koski A, Heymann J. Thirty-year trends in the prevalence and severity of female genital mutilation: a comparison of 22 countries. BMJ Global Health. 2017;2(e000467).

7. Njue C, Askew I. Medicalization of female genital cutting among the Abagusii in Nyanza Province, Kenya. 2004. http://www. carraguard.org/pdfs/FRONTIERS/FR_FinalReports/Kenya_FGC_ Med.pdf

8. Mepukori DN. Is alternative rite of passage the key to abandonment of female genital cutting? A case study of the Samburu of Kenya. Duke University; 2016.

9. Christoffersen-Deb A. "Taming tradition": medicalized female genital practices in western Kenya. Med Anthropol Q. 2005 Dec;19(4): 402-18 http://www.ncbi.nlm.nih.gov/pubmed/16435647.

10. Askew I, Chaiban T, Kalasa B, Sen P. A repeat call for complete abandonment of FGM. J Med Ethics. 2016;42(9):619-20.

11. Bjälkander O, Grant DS, Berggren V, Bathija H, Almroth L. Female genital mutilation in sierra leone: forms, reliability of reported status, and accuracy of related demographic and health survey questions. Obstet Gynecol Int 2013(680926).

12. Isa AR, Shuib R, Othman MS. The practice of female circumcision among Muslims in Kelantan, Malaysia. Reprod Health Matters. 1999; 7(13):137-44.

13. Merli C. Negotiating female genital cutting (sunat) in Southern Thailand. In Self-determination and women's rights in Muslim Societies. Raghavan C, Levine J, editors. Brandeis University Press; 2012. 169-187 p.

14. Newland L. Female circumcision: Muslim identities and zero tolerance policies in rural West Java. Women's Stud Int Forum. 2006;29: 394-404.

15. Taher M. Understanding female genital cutting in the Dawoodi Bohra Community: an exploration survey. 2017.

16. Feillard A, Marcoes L. Female circumcision in Indonesia: to "Islamize" in ceremony or secrecy. Archipel. 1998;56:337-67.

17. Budiharsana M, Amaliah L, Utomo B, Erwinia. Female circumcision in Indonesia: extent, implications and possible interventions to uphold women's health rights. Jakarta; 2003.

18. Van Baelen L, Ortensi L, Leye E. Estimates of first-generation women and girls with female genital mutilation in the European Union, Norway and Switzerland. Eur J Contracept Reprod Health Care. 2016;21(6):474-82. https://doi.org/10.1080/13625187.2016. 1234597.

19. Berns MGR. Muslims in the diaspora: the Somali communities of London and Toronto. Toronto: University of Toronto Press; 1999.

20.• Wahlberg A, Johnsdotter S, Ekholm Selling K, Källestål C, Essén B. Factors associated with the support of pricking (female genital cutting type IV) among Somali immigrants - a cross-sectional study in Sweden. Reproductive Health; 2017;14(92). https://doi.org/10. 1186/s12978-017-0351-0. This cross-sectional study explores important factors for supporting the continuation of pricking.

21. Berg RC, Denison E. A tradition in transition: factors perpetuating and hindering the continuance of female genital mutilation/cutting (FGM/C) summarized in a systematic review. Health Care Women Int 2013;34(10):837-59 http:// www.pubmedcentral.nih.gov/articlerender.fcgi?artid= 3783896\&tool $=$ pmcentrez\&rendertype $=$ abstract.

22. Farina P, Ortensi LE. The mother to daughter transmission of female genital cutting in emigration as evidenced by Italian survey data. Genus. 2014;70(2):111-37. 
23. Wahlberg A. Continuity or change? Improved understanding of attitudes towards female genital cutting after migration from Somalia to Sweden. Uppsala University; 2017. This PhD thesis investigates the impact of migration on cultural change regarding FGC with a particular focus on the practice of pricking.

24. Abdulcadir J, Margairaz C, Boulvain M, Irion O. Care of women with female genital mutilation/cutting. Swiss med wkly. 2011;(January).

25. Coleman DL. The Seattle compromise: multicultural sensitivity and americanization. Duke Law J. 1998;47:717-83.

26. AAP. Policy statement - ritual genital cutting of female minors. Pediatrics. 2010;125(5):1088-93. https://doi.org/10.1542/peds. 2010-0187.

27.• Arora KS, Jacobs AJ. Female genital alteration: a compromise solution. J Med Ethics. 2016;42:148-54. This study provides arguments for why practices such as pricking should be tolerated.

28. Zurynski Y, Elliott E. No compromise on female genital mutilation. J Paediatr Child Health. 2017;53(6):612-2. https://doi.org/10.1111/ jpc.13581.

29.• Earp BD. In defence of genital autonomy for children. J Med Ethics. 2016;42(3):158-63. This study provides a thorough description of why all forms of genital cutting on children should not be tolerated.

30. Macklin R. Not all cultural traditions deserve respect. J Med Ethics. 2016;42:155.

31. Johnsdotter S. Created by God. How Somalis in Swedish exile reassess the practice of female circumcision: Lund University; 2002.

32. Chu T, Akinsulure-Smith AM. Health outcomes and attitudes toward female genital cutting in a community-based sample of West African immigrant women from high-prevalence countries in New York City. J Aggress Maltreat Trauma. 2016;25(1):63-83. https:// doi.org/10.1080/10926771.2015.1081663.

33. Akinsulure-Smith AM, Chu T. Knowledge and attitudes toward female genital cutting among West African male immigrants in New York City. Health Care Women Int 2017;38(5):463-77. https://doi.org/10.1080/07399332.2017.1294593.

34. Behrendt A. Listening to African voices: female genital mutilation/ cutting among immigrants in Hamburg: knowledge, attitudes and practice. Hamburg; 2011.

35. Johnsdotter S, Moussa K, Carlbom A, Aregai R, Essén B. "Never my daughters": a qualitative study regarding attitude change toward female genital cutting among Ethiopian and Eritrean families in Sweden. Health Care Women Int 2009;30(1-2):114-33 http:// www.ncbi.nlm.nih.gov/pubmed/19116825.

36. Wahlberg A, Johnsdotter S, Ekholm Selling K, Källestål C, Essén B. Baseline data from a planned RCT on attitudes to female genital cutting after migration: when are interventions justified? BMJ Open. 2017;7(8):e017506. https://doi.org/10.1136/bmjopen-2017017506.

37. Gele AA, Johansen EB, Sundby J. When female circumcision comes to the West: attitudes toward the practice among Somali Immigrants in Oslo. BMC public health. BMC Public Health; 2012;12(697). http://www.pubmedcentral.nih.gov/articlerender. fcgi?artid $=3519553 \&$ tool $=$ pmcentrez\&rendertype $=$ abstract

38. Gele AA, Kumar B, Hjelde KH, Sundby J. Attitudes toward female circumcision among Somali immigrants in Oslo: a qualitative study. Int J Women's Health. 2012;4:7-17 http://www.pubmedcentral.nih.gov/ articlerender.fcgi?artid=3271810\&tool=pmcentrez\&rendertype $=$ abstract.

39. Exterkate M. Female genital mutilation in the Netherlands: prevalence, incidence and determinants. Utrecht: 2013.

40. Shell-Duncan B, Hernlund Y. Are there "stages of change" in the practice of female genital cutting?: qualitative research finding from Senegal and the Gambia. Afr J Reprod Health. 2006;10(2):57-71. https://doi.org/10.2307/30032459.
41. Hodes D, Armitage A, Robinson K, Creighton SM. Female genital mutilation in children presenting to a London safeguarding clinic: a case series. Arch Dis Child. 2016;101:212-6. This study describes challenges in identifying pricking at a paediatric clinic.

42. Creighton SM, Dear J, De Campos C, Williams L, Hodes D. Multidisciplinary approach to the management of children with female genital mutilation (FGM) or suspected FGM: service description and case series. BMJ Open. 2016;6:e010311.

43. Zurynski Y, Phu A, Sureshkumar P, Cherian S, Deverell M, Elliott E. Female genital mutilation in children presenting to Australian paediatricians. Arch Dis Child. 2017;102(6):509-15. https://doi. org/10.1136/archdischild-2016-311540.

44. EIGE. Female genital mutilation in the European Union and Croatia. Vilnius; 2013.

45. SFS 1982:316. Lag med förbud mot könsstympning av kvinnor [Act prohibiting female genital mutilation of women]. Stockholm; 1982.

46. Council of Europe. Convention on preventing and combating violence against women and domestic violence. Istanbul; 2011.

47. Laurence E. Genital mutilation convictions overturned after new evidence showing victims remain intact. ABC. 2018. https://www. abc.net.au/news/2018-08-11/genital-mutilation-convictionsoverturned/10108106

48. Rogers JB. The first case addressing female genital cutting in Australia: where is the harm? AltLJ. 2016;41(4):235-8.

49. Huffman A. Emergency physician arrest raises questions about female genital mutilation in United States. Annals of Emergency Medicine. American College of Emergency Physicians; 2017;70(4):A20-2. https://doi.org/10.1016/j.annemergmed.2017. 08.012

50. Snell R. Genital mutilation ban ruled unconstitutional; judge drops charges against sect. Detroit: The Detroit News; 2018 Nov 21. https://eu.detroitnews.com/story/news/local/detroit-city/2018/11/ 20/judge-dismisses-key-count-genital-mutilation-case/ 2066855002/

51. Darby R. Moral hypocrisy or intellectual inconsistency? A historical perspective on our habit of placing male and female genital cutting in separate ethical boxes. Kennedy Institute of Ethics Journal. 2016;26(2):155-63.

52. Hernlund Y, Shell-Duncan B. Transcultural positions: negotiating rights and culture. In: Hernlund Y, Shell-Duncan B, editors. Transcultural bodies: female genital cutting in global context. New Brunswick: Rutgers University Press; 2007. p. 1-43.

53. Earp BD. Does female genital mutilation have health benefits? The problem with medicalizing morality. Quillette Magazine. 2017; (August 15).

54. Arora KS, Jacobs AJ. Response to WHO. J Med Ethics. 2016;42(9):620-0. https://doi.org/10.1136/medethics-2016103606.

55. Onsongo N. Female genital cutting (FGC): who defines whose culture as unethical? International Journal of Feminist Approaches to Bioethics. 2017;10(2):105-23.

56. Latham S. The campaign against female genital cutting: empowering women or reinforcing global inequity? Ethics and Social Welfare. 2016;6535(April).

57. Barrett H, Brown K, Beecham D, Otoo-Oyortey N, Naleie Z. Researching female genital mutilation (FGM): intervention programmes linked to African communities in the EU. 2011.

58. Brown K, Beecham D, Barrett H. The applicability of behaviour change in intervention programmes targeted at ending female genital mutilation in the EU: integrating social cognitive and community level approaches. Obstetrics and gynecology international. 2013 Jan;324362. http://www.pubmedcentral.nih.gov/ articlerender.fcgi?artid=3745976\&tool=pmcentre $z \&$ rendertype $=$ abstract 
59. Richard F. Why we should be against the medicalisation of female genital mutilation. 2016.

60. Berg RC, Underland V. Immediate health consequences of female genital mutilation/cutting $(\mathrm{FGM} / \mathrm{C})$. Oslo: Report from Kunnskapssenteret; 2014.

61. Obiora LA. Bridges and barricades: rethinking polemics and intransigence in the campaign against female circumcision. Cas W Res L Rev. 1997;47(2):275-378.

62. Shweder RA. What about "female genital mutilation"? And why understanding culture matters in the first place. Daedalus. 2000;129(4):209-32.

63.• Wahlberg A, Essén B, Johnsdotter S. From sameness to difference: Swedish Somalis' post-migration perceptions of the circumcision of girls and boys. Culture, health \& sexuality. 2018. https://oi.org/ $10.1080 / 13691058.2018 .1502472$. This qualitative study explores migrants' perceptions of non-therapeutic male genital cutting and female genital cutting/pricking.

64. Leye E, Powell R a, Nienhuis G, Claeys P, Temmerman M. Health care in Europe for women with genital mutilation. Health care for women International 2006;27(4):362-378. http://www.ncbi.nlm. nih.gov/pubmed/16595367.

65. World Health Organization. WHO guidelines on the management of health complications from female genital mutilation. Geneva; 2016.

66. Muteshi J, Sass J. Female genital mutilation in Africa: an analysis of current abandonment approaches. Nairobi; 2005.

67. Kimani S, Shell-Duncan B. Medicalized female genital mutilation/ cutting: contentious practices and persistent debates. Curr Sex Health Rep. 2018;10(1):25-34. https://doi.org/10.1007/s11930018-0140-y.

68. Shell-Duncan B, Moore Z, Njue C. The medicalization of female genital mutilation/cutting: what do the data reveal? Evidence to end
FGM/C: research to help women thrive. New York: Medical anthropology quarterly; 2017.

69. Leye E, Ysebaert I, Deblonde J, Claeys P, Vermeulen G, Jacquemyn Y, et al. Female genital mutilation: knowledge, attitudes and practices of Flemish gynaecologists. Eur J Contracept Reprod Health Care. 2008 Jun;13(2):182-90 http://www.ncbi.nlm.nih.gov/ pubmed/18465481.

70. Cappon S, L'Ecluse C, Clays E, Tency I, Leye E. Female genital mutilation: knowledge, attitude and practices of Flemish midwives. Midwifery. 2015;31(3):e29-35.

71. Abu-Sahlieh SAA. To mutilate in the name of Jehovah or Allah: legitimization of male and female circumcision. Med Law. 1994;13: 575-622.

72. Gele AA, Bø BP, Sundby J. Attitudes toward female circumcision among men and women in two districts in Somalia: is it time to rethink our eradication strategy in Somalia? Obstet Gynecol Int. 2013;312734 http://www.pubmedcentral.nih.gov/articlerender. fcgi?artid=3654358\&tool=pmcentrez\&rendertype $=$ abstract.

73. Johnsdotter S. Somali women in western exile: reassessing female circumcision in the light of Islamic teachings. Journal of Muslim Minority Affairs. 2003;23(2):361-73. https://doi.org/10.1080/ 1360200032000139983.

74. Johansen REB. Undoing female genital cutting: perceptions and experiences of infibulation, defibulation and virginity among Somali and Sudanese migrants in Norway. Culture, Health \& Sexuality. 2016; 19(4). https://doi.org/10.1080/13691058.2016. 1239838

Publisher's Note Springer Nature remains neutral with regard to jurisdictional claims in published maps and institutional affiliations. 